\title{
Permafrost Changes in Europe During the Last Glacial
}

\section{J. Vandenberghe}

Institute of Earth Sciences, Vrije Universiteit, De Boelelaan 1085, 1081 HV Amsterdam, The Netherlands and

A. Pissart

Géomorphologie et Géologie du Quaternaire, Université de Liège, Place du 20 Août, 7, B-4000 Liège, Belgium

\begin{abstract}
Reconstruction of former permafrost is based on specific indicators which represent relics of features developed above or within the permafrost. Their interpretation in terms of genesis and (palaeo)climatic significance, however, is in some cases still under debate. Previously the reconstruction of the periglacial environment in Europe was limited to permafrost mapping during the coldest time of the last glaciation. Today a much more refined evolution of the palaeoclimate of the last glacial has been established, thanks to a considerable increase in registered periglacial indicators, a better understanding of the corresponding climate conditions, and more accurate and reliable dating of the periglacial phenomena.
\end{abstract}

\section{RÉSUMÉ}

La reconnaissance de l'existence d'un pergélisol ancien est basée sur des indicateurs qui sont les traces de phénomènes développés au-dessus et au sein du pergélisol. Leur interprétation en termes de genèse et de signification paléoclimatique est toutefois dans quelques cas, toujours en discussion. Autrefois la reconnaissance de l'environnement périglaciaire en Europe était limitée à la cartographie du pergélisol au moment du maximum du froid de la dernière glaciation. Actuellement, une meilleure reconstitution de l'évolution du climat pendant la dernière période froide est établie grâce à une augmentation considérable des indicateurs périglaciaires, une meilleure compréhension de leur signification paléoclimatique et une datation plus précise et plus fiable des phénomènes périglaciaires.

KEY WORDS: Palaeoclimate Weichselian Permafrost Last glacial Periglacial

\section{INTRODUCTION}

Changes in periglacial conditions and permafrost distribution are well documented in the geological evolution of Europe. Quaternary geomorphological, palaeontological and geological records thus provide the possibility not only to appreciate the characteristics of previous cold environments but also to estimate the rate of change of certain palaeoclimatic parameters. It is the aim of the present contribution to illustrate the principles of reconstruction of spatial distribution and temporal evolution of permafrost for west and central Europe, a region with a long history of alternations between cold (peri)glacial conditions and more temperate climates. 
The reconstruction of former periglacial environments implies comparison with present-day periglacial environments. More specifically, frostthaw action provides many diagnostic geomorphological forms and sedimentary structures. The preserved traces of these phenomena permit the reconstruction of former periglacial conditions. It is obvious that only those periglacial phenomena which have high conservation chances of their original form (e.g. stone circles) or a derived form after ground-ice thaw (e.g. pingo remnants) can be taken into consideration.

In this respect, it is important to realize that present-day permafrost regions show a high diversity in environmental conditions and vegetation. Apart from factors such as soil composition, topography and hydrological conditions, summer temperature is the main factor determining the vegetation pattern. However, winter and mean annual temperatures govern the establishment and preservation of perennially frozen soil. This means that the different kinds of permafrost may best be approximated by the mean annual temperatures. In general, climatic data are expressed as air temperatures. Unfortunately, there is no precise relation between the mean annual air temperature and the mean annual soil temperature. The latter determines the occurrence of permafrost and is commonly $1-6^{\circ} \mathrm{C}$ warmer than air temperature (Washburn, 1979). Thus, only approximations exist between permafrost and mean annual air temperature. In Canada the southernmost limit of permafrost coincides approximately with the mean annual isotherm of $-1.1^{\circ} \mathrm{C}$ (Brown, 1969). In the southern boreal forest permafrost is only sporadic but becomes discontinuous as one moves northward. The $-6.7^{\circ} \mathrm{C}$ isotherm forms roughly the transition to the region where the permafrost is spatially continuous (Brown, 1969). It is necessary to repeat that these values are only mean values and depend on lithology, vegetation and geomorphological position (Nelson, 1989).

Reconstruction of former permafrost environments are based on the detection, recognition and evaluation of permafrost indicators. Therefore, diagnostic characteristics of permafrost are discussed first. Their significance is related to their preservation chances and palaeoclimatic relevance. However, a number of problems still exist arising from use of these permafrost indicators. Second, the criteria so defined enable one to reconstruct the spatial distribution of permafrost in western and central Europe during the cold maxi- mum of the last glacial. Third, the high variability and multiple changes of permafrost environments in time are illustrated for the same region during the last glacial.

\section{PERMAFROST INDICATORS}

From the numerous periglacial features only a very limited number testify to former permafrost (see, e.g., Washburn, 1980).

\section{Ice-wedge Casts}

Pseudomorphs of ice wedges constitute a reliable proof of the earlier occurrence of permafrost. Besides, they are numerous in Quaternary deposits and have been described on many occasions (e.g. Gozdzik, 1973). When permafrost disappears and the ice in the wedge melts, the free space is filled with surrounding and overlying sediment. In sandy soils this results in a twofold fill (Figure 1): a central part with vertical laminated sediment and an outer part consisting of blocks which have moved downwards along normal faults (Vandenberghe, 1983b). On top of the former wedge the sediments show a striking wide downward bending which may form part of an extended cryoturbation level (Vandenberghe and Krook, 1981). Silt or clay subsoils are more cohesive during permafrost degradation, so the original upturning structures may be preserved, whereas in less cohesive sand subsoils the latter structures are destroyed by the subsiding movements.

Classically, ice-wedge patterns are attributed to the zone of continuous permafrost (e.g. Péwé, 1966). The latter author reports a minimum mean annual air temperature of $-6^{\circ} \mathrm{C}$ according to their occurrence in Alaska and Canada. Later, values of $-4.5^{\circ} \mathrm{C}$ have been recorded in the same region for loamy subsoils (Brown \& Péwé, 1973). According to data obtained by Romanovsky (1985) in the USSR, ice wedges form in fine sediments at higher temperatures than in coarser sediments. When translating Romonovsky's ground temperatures we arrive at minimum mean annual air temperatures of $-4.5 \mathrm{C}$ for loamy soils and $-8^{\circ} \mathrm{C}$ for sandy and gravelly soils (Vandenberghe, 1992a). Romanovsky's observations on the effect of soil lithology on ice-wedge formation have also the important consequence that in marginal temperature conditions ice-wedge polygons may occur in discontinuous permafrost, but only at favourable sites. 


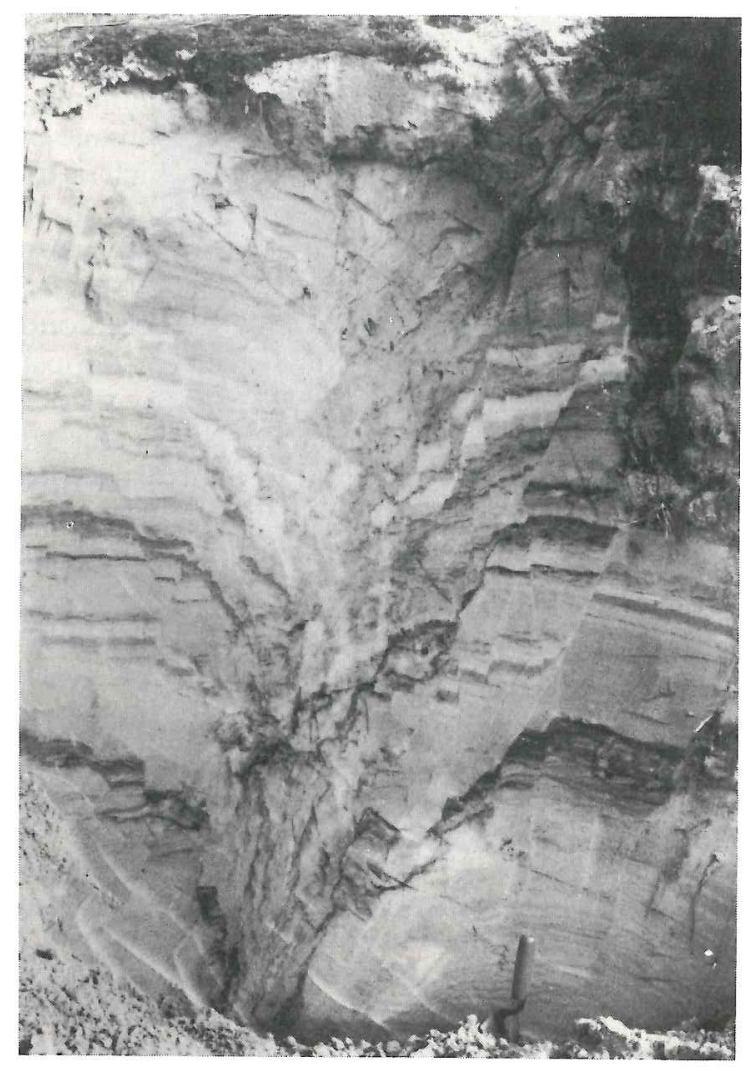

Figure 1 Ice-wedge cast from the last glacial maximum at Grubbenvorst (The Netherlands), illustrating the internal (vertical laminated) infilling and the external blockwise downfaulting.

\section{Sand-wedge Casts}

Contraction fissures may be filled from the surface with allochtonous sediment, mostly sand. Infilling usually takes place by wind. This recurrent seasonal process results also in the progressive enlargement of the wedge and a vertical lamination of the infilling. Sand-wedge casts are easily distinguished from ice-wedge casts, as the former reach the surface level (while the top of the ice-wedge casts represents the permafrost table) and the upturning structures in the sediment adjacent to the sand wedge are always preserved. Besides, the aeolian activity during the development of sand-wedge polygons results usually in the development of a desert pavement at the surface. Sand-wedge casts from Quaternary deposits have been reported only sporadically (Karte, 1979; Vandenberghe, 1983a; Gozdzik, 1986).

Sand-wedge polygons can only develop in very dry conditions. The reason for the development of sand wedges is dryness. Because no water descends into the frost crack, the filling consists only of sand. A pure sand wedge (without ice) only develops when the temperature remains below $0{ }^{\circ} \mathrm{C}$ during the whole year or when no water is available because of the absence of summer rain or spring snow. Since such conditions are rare in periglacial environments, most sand wedges are composite in nature (with a certain amount of ice). According to Karte (1979), a minimum mean annual air temperature below $-12^{\circ} \mathrm{C}$ and an annual precipitation less than $100 \mathrm{~mm}$ is required for pure sand wedges. However, composite sand wedges are very similar to fissures or wedges which appear in the active layer or in the seasonally cryotic layer outside the permafrost zone. The latter are usually smaller and shallower than the sand wedges which form in perennially frozen soil. The former have been reported by Kolstrup (1987) and may also be observed in the eastern Netherlands (Figure 2). It may be concluded that composite sand-wedge casts testify to conditions of only deep seasonal frost and low precipitation.

\section{Remnants of Pingos and Palsas}

Numerous closed depressions have been interpreted as the result of the melting of ice lenses in cryogenic mounds. In many cases no other interpretation can be found. It is clear that supplementary arguments on genesis and age are necessary in order to draw any palaeoclimatic conclusion based on the occurrence of these forms. The interpretation of depressions surrounded by ramparts is more obvious. These forms result from the upheaval and subsequent movements of soil due to ice-lens growth. Only the rampart forms allow of the derivation of palaeoclimatic parameters.

In present-day periglacial areas closed-system pingos occur only in the zone of continuous permafrost at mean annual temperatures of maximum $-6^{\circ} \mathrm{C}$. Open-system pingos, however, occur also in the discontinuous permafrost zone at mean annual temperatures up to $-2^{\circ} \mathrm{C}$. Thus, for the purpose of palaeoclimatic reconstruction, it is necessary to find out the exact origin of the pingo remnant.

Traces of former organic palsas are not well known. They are difficult to recognize as usually they are buried by further peat growth after the thaw of the palsa-ice. Organic palsas develop at 


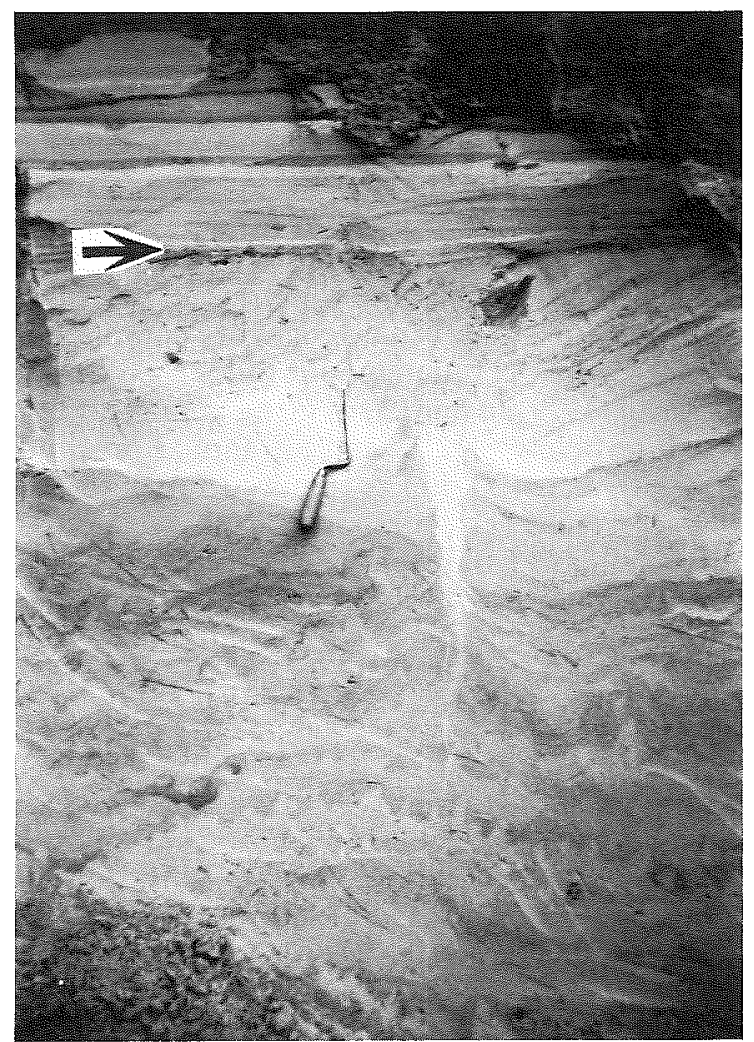

Figure 2 Composite sand-wedge cast associated with desert pavement (Beuningen horizon (arrow), Weichselian Late Pleniglacial) in the Dinkel section (eastern Netherlands).

mean annual temperatures of max. $-1^{\circ} \mathrm{C}$. Palsas without an isolating peat cover, however, need more rigorous conditions: $-4^{\circ} \mathrm{C}$ to $-6^{\circ} \mathrm{C}$ mean annual temperature according to their present distribution (Dewez et al., 1985). It means that these mineral palsas are situated in the northernmost part of the zone of discontinuous permafrost. An example of remnants of mineral palsas is described on the Ardennes Plateau (eastern Belgium) by Pissart (1983) (Figure 3).

\section{Traces of Segregation Ice and Absence of Speleothems in Caves}

Sediments in caves may contain segregation ice when they remain frozen throughout the year and the humidity is sufficient. Since horizontal caves at sufficient depth show a constant temperature which is approximately equal to the mean annual air temperature, the traces of segregation ice in cave sediments point to the presence of former permafrost. As an example we may mention the traces of segregation ice in the cave sediments at Remouchamps (eastern Belgium) with an age between 11000 and 34000 years BP, which is the time that also no water could penetrate in the subsoil, owing to the presence of perennially frozen ground above the cave (Pissart et al., 1988).

Apart from some exceptions with special conditions, traces of ice segregation in cave deposits point to thick permafrost. In regions with deep caves it is even possible to determine in this way the approximate depth of the permafrost. Otherwise, if a perennially frozen subsoil is present, no water can penetrate into the subsoil and no speleothems can form. Therefore, phases without speleothems point to the existence of continuous permafrost at that time.

\section{Cryoturbations}

Involutions of a periglacial nature may have different origins (Vandenberghe, 1988). Cryohydrostatic pressure results in the extrusion of sediment-laden water. Cryostatic pressure caused by ice segregation may induce involutions in fine sediments by repeated freeze-thaw cycles (Pissart, 1982). The deformations resulting from cryostatic and cryohydrostatic pressure are, in general, randomly spaced, except when induced by pre-existing lithological distributions. Both processes may be active without the presence of permafrost. Upward injection through frost fissures in polygonal patterns is a special form of a hydrostatic process giving rise to structures similar to those described by Van Vliet-Lanoë (1983). The latter process requires the presence of frozen ground to maintain the necessary water pressure.

Equally spaced and widely extending, regular forms of large and constant amplitude (1-2 m) are attributed by one of us (Vandenberghe and Van den Broek, 1982; Vandenberghe, 1983a) to the loading mechanism induced by the melting of the ice-rich top of permafrost and subsequent oversaturation at that level. This explanation is supported by (1) the occurrence of this type of involution independent of the frost susceptibility of the soil and (2) the sediment-structural framework of these involutions, which is identical with the structures of experimentally obtained load casts (Vandenberghe, 1992b). This explanation involves the presence of underlying permafrost, which is confirmed by the flat-bottomed form of 


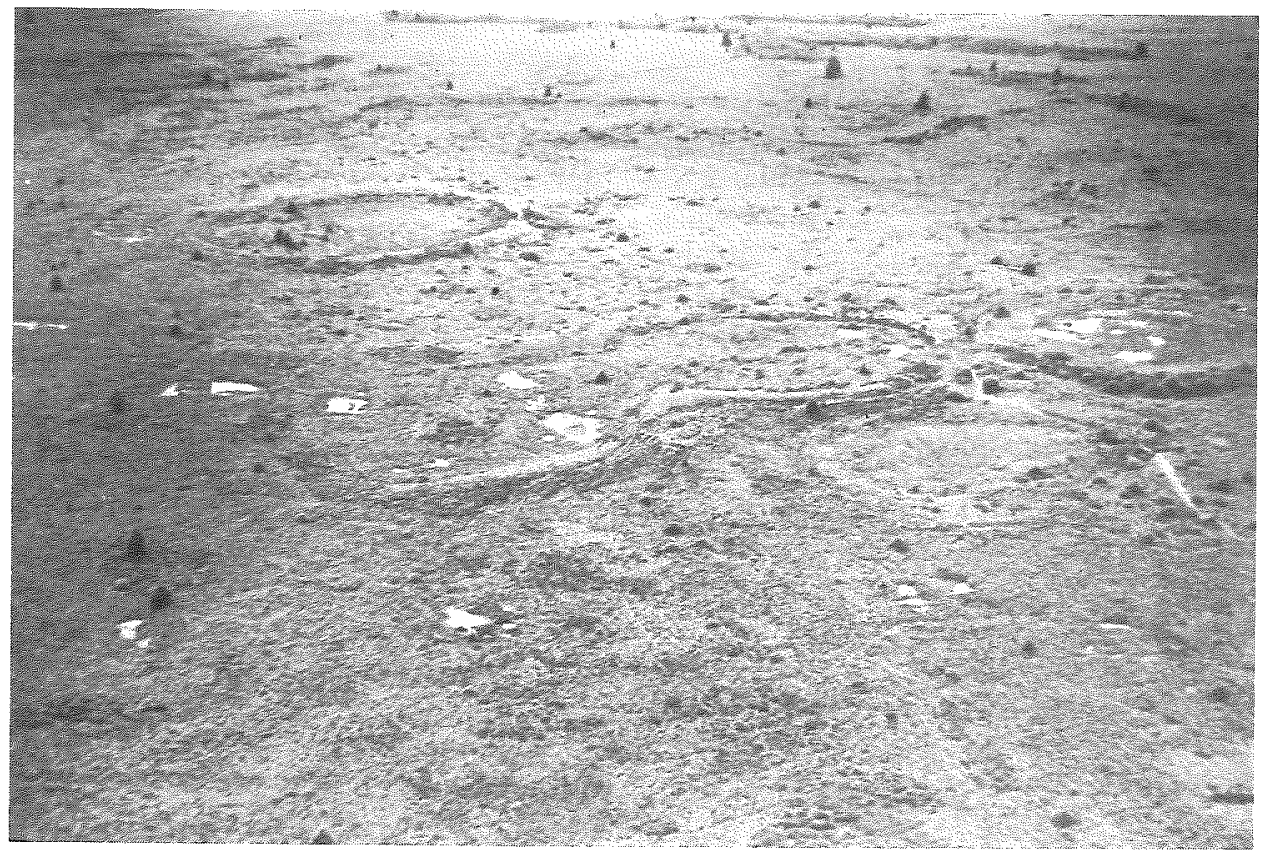

Figure 3 Remnants of mineral palsas which grew during the Younger Dryas at $500 \mathrm{~m}$ a.s.l. on the Hautes Fagnes (Belgium).

many of these involutions and the occurrence of ice-wedge casts just below the involutions at many localities (Vandenberghe, 1983b, 1985). Consequently, the same palaeoclimatic implications as for ice-wedge casts may be derived from large-amplitude cryoturbations: less than $-4.5^{\circ} \mathrm{C}$ to $-8^{\circ} \mathrm{C}$, depending on the lithology (see above).

Regularly developed involutions, as described above but with small amplitude and of minor extent, may also develop by occasional loading on top of deep seasonally frozen ground (Vandenberghe, 1988). The same holds for isolated dropstructures which may be caused by short-lasting and local conditions of supersaturation. Their palaeoclimatic significance is thus rather low.

\section{PROBLEMS IN PALAEOCLIMATIC RECONSTRUCTION BY PERIGLACIAL MARKERS}

Conditions under which specific periglacial phenomena appear are certainly not always completely understood, while their present distribution is often unknown. Besides, the determination of the factors governing the distribution of certain periglacial forms is very complex and, more particu- larly, the air temperature associated with their appearance is often difficult to determine. This is a consequence of the fact that most of the periglacial phenomena are controlled by soil temperatures. The latter are a function of multiple factors and may show differences of up to $10^{\circ} \mathrm{C}$ under the same air temperature (Smith, 1975). Consequently, even if the relation between a specific periglacial phenomenon and the mean soil temperature can be established, the precise derivation of the mean annual temperature is not always obvious.

The transposition of present-day periglacial data from the Arctic towards relict Pleistocene periglacial conditions in nowadays temperate regions induces supplementary problems. The insolation values at nordic latitude are quite different from those that existed at more southern latitudes. Other climatic uncertainties pose even more important problems. One is the considerable perturbation of the atmospheric circulation which must have existed in the neighbourhood of the large ice-caps. Otherwise, oceanic studies of foraminifera show the absence of the warm Gulf Stream in the present North Sea, while the North Atlantic ice cap reached western Europe. These examples illustrate the important changes in re- 
gional systems which are superposed on global climatic evolution.

The adequate genetic correlation of Pleistocene periglacial forms with present ones is not always evident. This may be illustrated by the 'viviers' on the Ardennes Plateau (eastern Belgium) which formerly were interpreted as pingo remnants but now are considered to be the traces of mineral palsas (see above). Since the environmental conditions governing both forms are not identical, a different palaeoclimatic interpretation results.

The use of periglacial phenomena as palaeoclimatic indicators necessitates the accurate dating of their appearance. In this respect, proposed ages are sometimes questionable and have to be managed with caution. Again, the 'viviers' of the Ardennes illustrate this kind of uncertainty: the 'viviers' do not date from the last glacial maximum, as was thought formerly, but from the Younger Dryas period (Pissart, 1983), as proposed in 1969 by Mullenders and Gullentops.

\section{PERMAFROST DISTRIBUTION IN (WESTERN AND CENTRAL) EUROPE}

As long ago as 1909 Lozinski recognized the important role of periglacial research in palaeoclimatic reconstructions. The first attempt of global significance was realized by Poser (1948). It was based on two criteria: (1) width and depth of ice-wedge casts for the recognition of permafrost and estimation of cold intensity; (2) involution depth as an indicator of the thickness of the active layer. In this way Poser was able to determine the southern limit of permafrost in Europe during the last glacial (Figure 4). His reconstruction of palaeotemperatures was quite remarkable. For that purpose he used the position of the northern tree limit with an estimated July temperature of $+10^{\circ} \mathrm{C}$ and the position of the southern limit of permafrost extension with an estimated mean annual temperature of $-2{ }^{\circ} \mathrm{C}$, which also corresponds with the mean April and October temperatures. On the basis of these criteria, he derived a decrease of $8-9^{\circ} \mathrm{C}$ for the mean summer temperature of the last glacial in comparison with the present-day situation, a decrease of $12^{\circ} \mathrm{C}$ for the mean winter temperature and a decrease of $10^{\circ} \mathrm{C}$ for the mean annual temperature. Strictly speaking, these values are only valid at the places where the northern tree limit meets the southern permafrost limit.

After this regional study, more attention was paid to more local investigations. Some modified Poser's results. For instance, the map of periglacial phenomena in France by Cailleux et al. (1956) shows a more southern position of the permafrost during the same period: up to latitude $45^{\circ} \mathrm{N}$, according to the occurrence of ice-wedge casts in gravel layers. This idea was followed by Kaiser (1960), who extended the southern permafrost limit to northern Italy (Figure 4).

In the whole region from Poland through Germany, the Netherlands and Belgium into France and Great Britain a high number of ice-wedge casts and large cryoturbations have been recorded. Together with pingo scars (e.g. in the northern Netherlands) and the traces of ice segregation (e.g. in east Belgium), they testify to continuous permafrost during the last glacial maximum.

As concerns the temperature distribution throughout the year, Williams (1975) demonstrated the continental character of the climate at the last glacial maximum. It was based on values of -8 to $-10^{\circ} \mathrm{C}$ for the mean annual temperature, according to the presence of a continuous permafrost, and a value of $+10^{\circ} \mathrm{C}$ for the mean July temperature, according to the thickness of the active layer and the presence of specific assemblages of coleoptera (Coope et al., 1971). This enabled Williams to derive winter temperatures of up to $-25^{\circ} \mathrm{C}$.

New permafrost maps were compiled by Maarleveld (1976) for the permafrost extension in the Weichselian and by Velichko (1982) for permafrost of the last glacial maximum (Figure 4). Their maps are very similar. Both authors place the southern limit of permafrost some $180 \mathrm{~km}$ more to the north than did Cailleux and Kaiser, and assume the Alps as the southern limit. It is possible that during previous glacials the northern Italian plain was also invaded by permafrost (cf. Kaiser, 1960). Finally, the very detailed inventories of permafrost indicators in central Europe made by Karte (1981) have to be mentioned as well as the reconstruction of the extent of permafrost on the base of cryopedological data by Van Vliet-Lanoë (1989).

\section{PALAEOCLIMATIC EVOLUTION OF WESTERN EUROPE DURING THE LAST GLACIAL}

\section{Weichselian Early Glacial}

The period between the Eemian interglacial and the Weichselian Pleniglacial took quite a long 


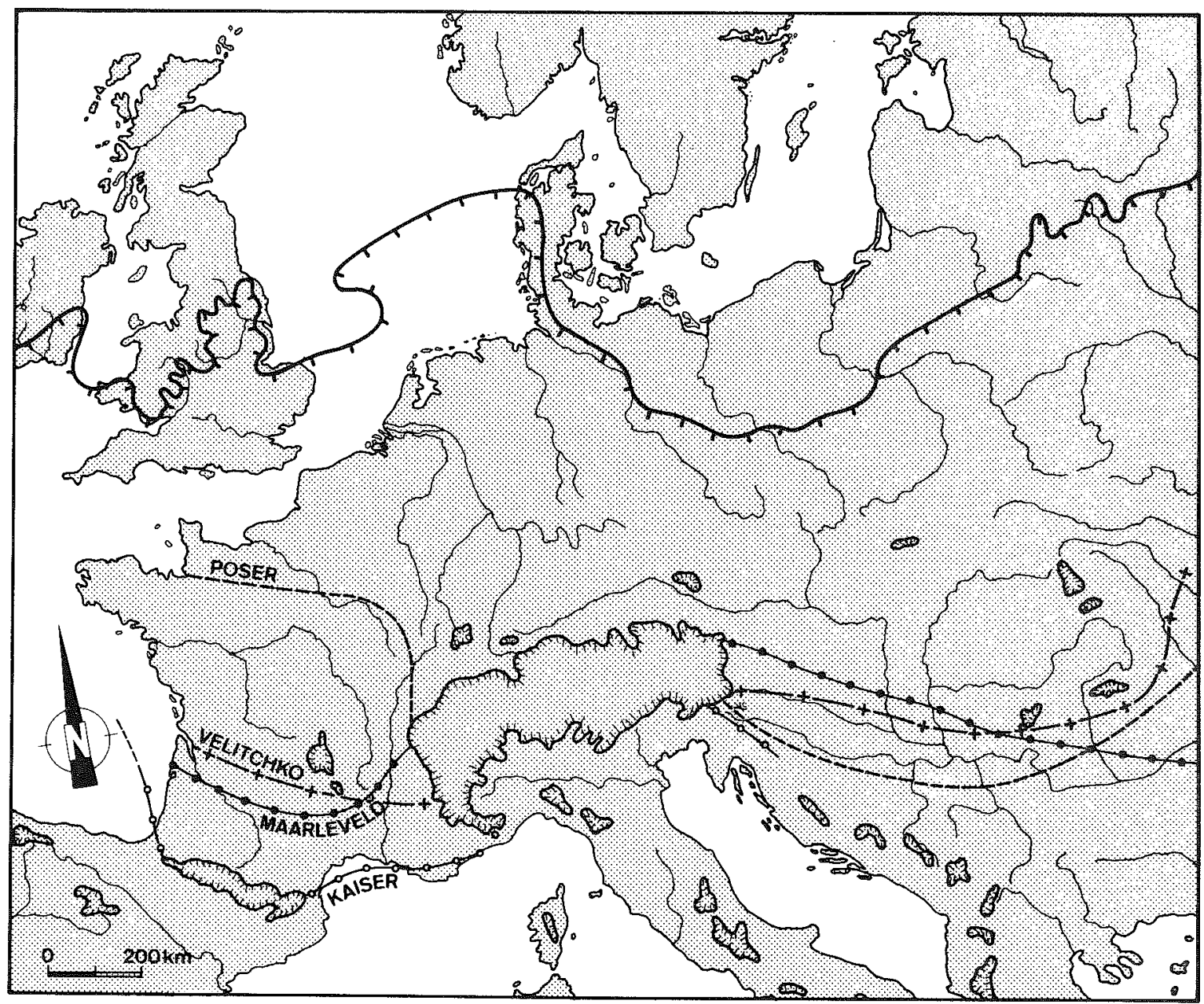

Figure 4 Map of western and central Europe showing the southern permafrost limits as proposed by Poser (1948), Kaiser (1960), Maarleveld (1976) and Velichko (1982), according to the distribution of periglacial phenomena dated from the last cold maximum.

time (from c. $110 \mathrm{ka}$ to $c .72 \mathrm{ka}$ ). In the oxygen isotope curve it corresponds with stages $5 \mathrm{~d}$-a (Woillard and Mook, 1982), a generally mild period. Therefore, it is not very surprising that periglacial phenomena from this time are rather scarce. Periglacial activity is situated in substages $5 \mathrm{~d}$, corresponding with the cold interval between Eemian and Brörup, and 5b, corresponding with the cold interval between Brörup (105-94 ka BP) and Odderade (85-73 ka BP). Small-scale cryoturbations and frost fissures are most common. They are reported by Zagwijn and Paepe (1968), De Moor et al. (1978), Haesaerts and Van VlietLanoë (1981), Lautridou and Sommé (1981) and Vandenberghe et al. (1985). These features point to periglacial conditions of deep seasonal frost, however, without the necessity of permafrost. It means the mean annual temperature was below $-1.5^{\circ} \mathrm{C}$ (Maarleveld, 1976).

The indications for permafrost in the northwest European lowlands are few. Ice-wedge pseudomorphs are mentioned by De Moor et al. (1978) for western Belgium.

\section{Weichselian Early Pleniglacial}

It was recognized by Van der Hammen et al. (1967) that the Pleniglacial could be subdivided into cold periods at the beginning and the end, 
separated by a milder interval in between. The Early Pleniglacial correlates with the first top in the oxygen isotope curve pointing to glacial conditions, i.e. stage 4 . It can be dated between $c .72$ $\mathrm{ka}$ and $61 \mathrm{ka}$ (Woillard and Mook, 1982; Vandenberghe, 1985).

Ice-wedge pseudomorphs and large, flatbottomed cryoturbations from the Early Pleniglacial can be attributed to that period in the Dutch-Belgian border region and in northwestern France (Lautridou and Sommé, 1981; Vandenberghe and Krook, 1981, 1985; Vandenberghe, 1985). These structures occur over large areas on subsoils varying from silts to fine and coarse sands. They undoubtedly testify to the former existence of continuous permafrost. In accordance with modern analogues, mean annual temperatures probably dropped below $-7^{\circ} \mathrm{C}$ (Karte, 1979; Romanovsky, 1985). For the English Midlands Williams (1975) estimated values not exceeding $-10^{\circ} \mathrm{C}$.

Similar indications for continuous permafrost have also been recognized by Zagwijn and Paepe (1968), West et al. (1974), Haesaerts and Van Vliet-Lanoë (1981), Van der Meer et al. (1984) and Haest et al. (1986). Sometimes observations have suffered from inadequate dating, but advanced stratigraphical knowledge now allows their assignment to the period concerned. In other cases the significance of certain structures as indicators for former continuous permafrost was not used by the authors. In this context special mention should be made of the unequivocal evidence for permafrost found at Stare Kurowo (Poland) in the form of a well-developed ice-wedge cast. Notwithstanding the age determination of Weichselian Early Glacial by Kozarski (1986), it is clear from his description that the wedge postdates the Odderade peat which it penetrates. Thus, an Early Pleniglacial age of the permafrost is obvious.

Figure 5 represents the temperature distribution during the Weichselian Pleniglacial and Late Glacial for the Netherlands and adjacent lowlands of Belgium and northern Germany. The mean summer temperatures are minimum values as derived from palaeobotanical analyses (Ran, 1990; Vandenberghe, 1992a), while the mean annual temperatures are maximum values obtained from periglacial information (Vandenberghe, 1983a). The mean winter temperatures are calculated from the annual and summer temperatures, supplemented with palaeobotanical and periglacial data.

\section{Weichselian Middle Pleniglacial}

The entire period between $c .61 \mathrm{ka}$ and $27 \mathrm{ka}$ is rather monotonous, as shown by palaeobotanical analyses, sedimentary environments and periglacial phenomena (Ran, 1990; Van Huissteden, 1990). It corresponds with oxygen isotope stage 3 and has been recognized as a milder period in between the preceding and the next cold stage (Van der Hammen, 1957; Van der Hammen et al., 1967; Vandenberghe, 1985, 1992a). In the sandy regions of western Europe the whole sediment sequence has been characterized by the occurrence of frost cracks and local, small-sized cryoturbations (Vandenberghe, 1983a). These features point at least to (deep) seasonal frost.

Permafrost had not been recognized in the Middle Pleniglacial of the northwest European lowlands until Van Huissteden (1990) found a polygonal network of ice-wedge casts accompanied at their top by large cryoturbations in Middle Pleniglacial deposits near Hengelo. At the same level large cryoturbations had been described by Zagwijn (1974). The episode concerned could accurately be dated between $36 \mathrm{ka}$ and $41 \mathrm{ka}$. Recently ice-wedge casts and associated cryoturbations of similar age have been discovered at Grouw (northern Netherlands) (Vandenberghe and Kasse, 1993). Common to all these cryogenic deformations is that they are formed exclusively on a silty or peaty substratum and up to now were not found on the widespread sandy subsoils of the region. A cold period around the same time has also been found in the Sclayn cave deposits by De Blaere and Gullentops (1986). According to Romanovsky (1985), ice wedges can form in fine-grained sediments when the mean annual ground temperature drops below $-2.7^{\circ} \mathrm{C}$ and mean annual air temperatures below $-4.5^{\circ} \mathrm{C}$ (Brown and Péwé, 1973). Since the distribution of surficial materials is related to geomorphological position, the latter is significant for the development of ice wedges and the distribution of permafrost (Pissart, 1987). The occurrence of ice-wedge casts and large cryoturbations only rarely and exclusively on favourable subsoils suggests that probably only discontinuous permafrost was present in that time interval in the sand regions and that mean annual temperatures were about $-5^{\circ} \mathrm{C}$.

As mentioned above, in the sandy regions of northwestern Europe no indications for permafrost have been found up to now from the Middle Pleniglacial, except for that period at $36-41 \mathrm{ka}$. It 


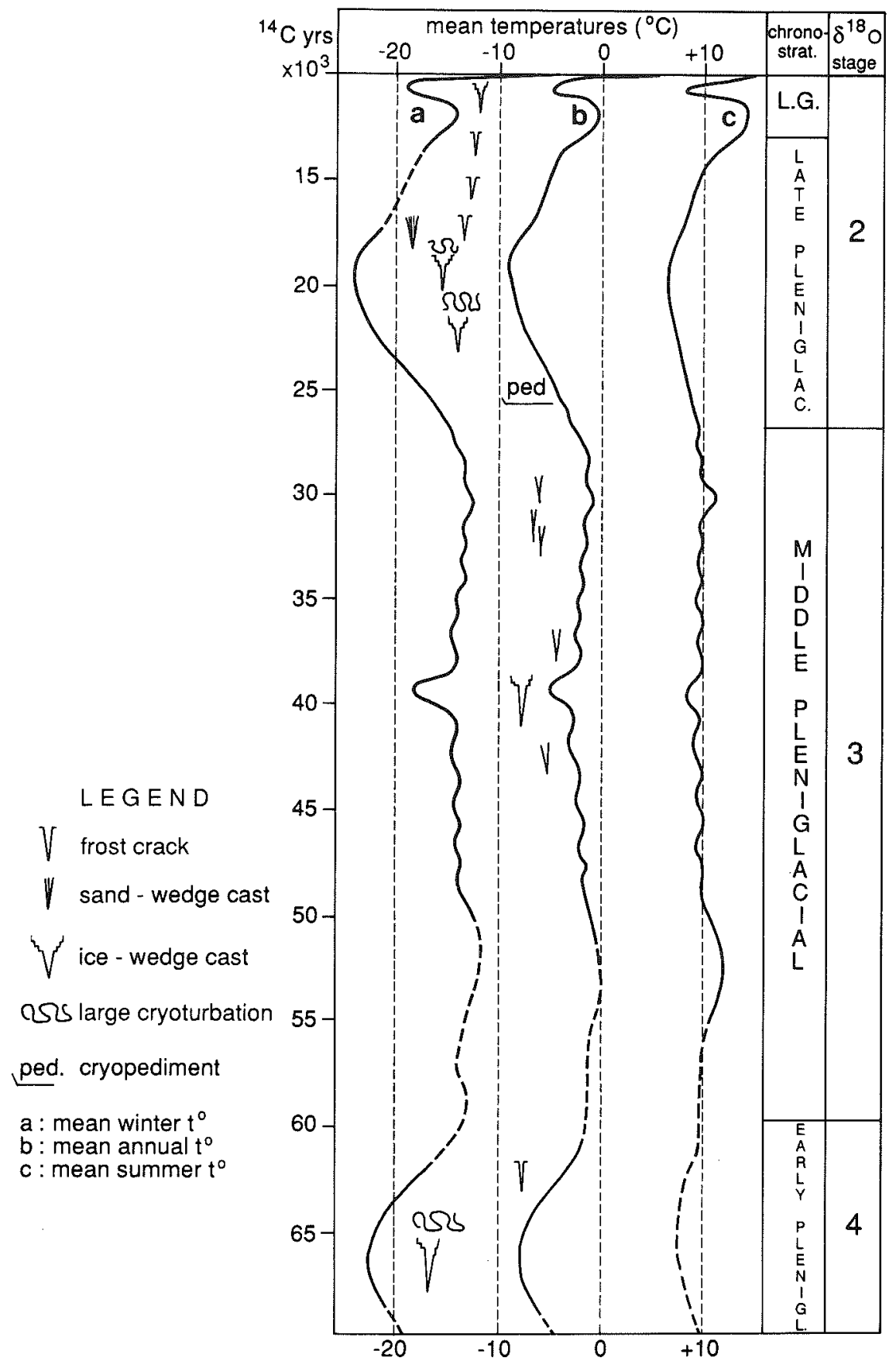

Figure 5 Mean annual, summer and winter temperatures during the Weichselian Pleniglacial and Lateglacial in the Netherlands and Belgium. 
follows that a mean annual temperature of $-4.5^{\circ} \mathrm{C}$ was indeed the lowest value reached during the Weichselian Middle Pleniglacial at sea level. The upper limit of the mean annual temperature can be derived from the occurrence of frost cracks and small-sized cryoturbations in all regions which necessitate mean annual temperatures below $-1.5^{\circ} \mathrm{C}$ (Maarleveld, 1976). In the adjacent loess belt isolated occurrences of icewedge casts have been found somewhat later than $36 \mathrm{ka}$ (Haesaerts and Van Vliet-Lanoë, 1981; Huijzer, 1991). The complete absence of speleothems in the caves of southern Belgium between $37 \mathrm{ka}$ and $14 \mathrm{ka}$ (Gewelt and Ek, 1988) is a good indication for the development of continuous permafrost in regions higher than $200 \mathrm{~m}$ a.s.1. In these situations maximum mean annual temperature was $-5^{\circ} \mathrm{C}$ and at sea level $-3^{\circ} \mathrm{C}$ between 35 $\mathrm{ka}$ and the end of the Middle Pleniglacial (Figure 5). In Scandinavia probably periods with permafrost were more frequent, according to the occurrence of ice-wedge casts described by Johnson (1984).

\section{Weichselian Late Pleniglacial}

This period lasted from c. $27 \mathrm{ka}$ to $13 \mathrm{ka}$ and corresponds to oxygen isotope stage 2 (Van der Hammen et al., 1967; Vandenberghe, 1985). It is also the period in which the last major ice advance took place (Van der Hammen, 1957). After the retreat of the ice caps in northern and central Europe, permafrost aggraded into the previously deposited tills (Liedtke, 1957/58; Williams, 1975; Kozarski, 1992).

Traces of periglacial structures from this period are widespread and generally well preserved. Icewedge casts and large flat-bottomed cryoturbations are very common and have been described many times, not only in loess subsoils (e.g. Paepe and Pissart, 1969; Haesaerts, 1974; Gullentops et al., 1981) but also in sands (e.g. Paepe and Van Hoorne, 1967; Van der Hammen et al., 1967; Van der Hammen and Wijmstra, 1971; Gozdzik, 1973; Kozarski, 1974; Maarleveld, 1976; Vandenberghe and Gullentops, 1977; Kolstrup, 1980; Vandenberghe and Krook, 1981, 1985; Vandenberghe, $1983 \mathrm{~b}$ ), and even in gravel(ly) deposits (Eissmann, 1981; Bryant, 1983). Karte (1981) provides additional references for Germany and Poland. In addition, in the northern Netherlands remnants of closed system pingos from the Late Pleniglacial are reported (De Gans, 1981). In the southern
Netherlands circular mounds have also been interpreted as pingo remnants, but they might only reflect the previous existence of ground ice lenses (Kasse and Bohncke, 1992).

Occasionally, sand-wedge casts have been mentioned (Gozdzik, 1973, 1986; Vandenberghe, 1983a; Kolstrup 1987). In comparison with typical sand wedges in present-day Arctic regions, the Pleniglacial wedge forms found in western Europe are much smaller and shallower (French and Gozdzik, 1988). Apart from the typical upturning structures of the adjacent sediments, some wedges also show downsinking structures. Like Gozdzik (1973), Kolstrup (1987) and Harry and Gozdzik (1988), we should like to interpret the described wedges as composite in nature. Their characteristics point to an origin which may have been of a recurrent but seasonal nature and even have contained some ice. Thus, it is important to state that composite sand-wedge casts do not necessitate the very severe conditions generally assumed for the typical deep sand wedges (see above).

Cryopedimentation is a process which frequently occurred even on soft sediments (Gullentops et al., 1966, 1981). Although difficult to date, it is believed that cryopediments formed in the early phase of the Late Pleniglacial. Although permafrost is not a prerequisite for their formation, they testify to deep seasonal frost and sparse vegetation at the beginning of the Late Pleniglacial.

The frequent occurrence of ice-wedge polygons and associated large-amplitude cryoturbations, the presence of closed-system pingos and the absence of speleothems in Belgium point to continuous permafrost. At the maximum of this cold period the ice wedges developed in all kinds of subsoils, including coarse sand and gravel deposits. From the latter it may be concluded that, in accordance with modern analogues, mean annual temperatures dropped below $-8^{\circ} \mathrm{C}$ at that time.

The final phase of the Late Pleniglacial (c.17$13 \mathrm{ka}$ ) was characterized by very dry conditions in which no more indications for permafrost have been observed, at least in the sand regions (Maarleveld, 1976; Vandenberghe, 1983a). Aeolian activity on a sparsely vegetated surface resulted in the formation of large deflation areas and the correlative deposition of large quantities of loess or cover sand, while fluvial activity was strongly reduced. Periglacial structures in the northwest European lowland were limited to small frost 
fissures and traces of hummocky soils and involutions. In central Europe permafrost continued perhaps until the end of the Pleniglacial (Kozarski, 1992).

\section{Weichselian Late Glacial}

The Late Glacial climatic improvement, which extended between $c .13 \mathrm{ka}$ and $10.9 \mathrm{ka}$, was characterized by warmer summers. However, winters remained fairly cold (Bohncke et al., 1987), so that seasonal frost cracks developed (Maarleveld, 1976; Van Geel et al., 1989).

The last part of the Late Glacial, the Younger Dryas, extended from c. 10900 to $c .10250$ years BP (Bohncke et al., 1987). It was characterized by a very abrupt cooling at the beginning of the period. It was also a time of distinct readvance of alpine glaciers and ice caps. In the northwest European lowlands the cooling was manifested by the frequent occurrence of isolated cryogenic disturbances and frost fissures (De Ploey, 1961; Van der Tak-Schneider, 1968). Regularly developed cryoturbations occur at specific locations (Van der Hammen and Maarleveld, 1952; Vandenberghe et al., 1991). De Moor and Heyse (1978) described large, flat-bottomed cryoturbations. Ice-wedge casts are exceptional and poorly developed (e.g. Vandenberghe et al., 1987). Even on the large loess plateaus, which form a favourable substratum for wedge development, no icewedge casts from the Younger Dryas have yet been recorded. However, more to the north, e.g. in southern Scandinavia, conditions were favourable for the development of well-formed icewedge polygons in the Younger Dryas (Svensson, 1988). Late Glacial ground-ice depressions are suggested by De Groot et al. (1987) in the northern Netherlands and by Sparks et al. (1972) in England.

On the Ardennes Plateau frost mounds have been interpreted as pingos by Pissart (1956) and Mullenders and Gullentops (1969), and later as palsas by Pissart (1983). On the German Shale Plateau many landforms show the imprint of periglacial conditions (gelifluction, slope deposits) and some features necessitated permafrost (ice-wedge casts) or at least deep seasonal frost (Karte, 1988).

These rather well documented and dated phenomena, which are characteristic of the first part of the Younger Dryas ending at c. $10550 \mathrm{BP}$, allow a reliable climatic reconstruction of this episode (Vandenberghe et al., 1991). The mineral palsas found above $500 \mathrm{~m}$ a.s.l. on the Ardennes Plateau point to a situation in the coldest zone of the discontinuous permafrost belt with mean annual temperatures between $-4^{\circ} \mathrm{C}$ and $-6^{\circ} \mathrm{C}$ (Dewez et al., 1985; Pissart, 1987). The incipient nature of the ice-wedge casts and their sparse occurrence would imply sporadic to discontinuous permafrost in the northwest European lowlands; it means mean annual temperatures between $-1.5^{\circ} \mathrm{C}$ and $-4.5^{\circ} \mathrm{C}$. At present, the mean annual temperature difference with the Ardennes Plateau is $3^{\circ} \mathrm{C}$ (Mullenders and Gullentops, 1969). In Scandinavia ice-wedge polygons point to continuous permafrost at that time and mean annual temperatures of less than $-6^{\circ} \mathrm{C}$.

The last part of the Younger Dryas (10550$10250 \mathrm{BP}$ ) is characterized by the disappearance of local permafrost in the northwest European lowlands. From this fact slightly increased temperatures are deduced. At the same time, precipitation decreased considerably, river activity declined and dunes formed.

\section{CONCLUSIONS}

Only periglacial features with wide occurrence, good preservation potential and a specific climatic significance are useful indicators for inferring the existence of previous permafrost and its nature.

For the reconstruction of the periglacial environment and its evolution in western Europe during the last glacial the following characteristics may be used.

(1) Continuous permafrost: widespread icewedge polygons, closed-system pingos, traces of ice segregation, absence of speleothems.

(2) Discontinuous permafrost: palsas, large cryoturbations, sporadic ice-wedge casts only on frost-susceptible soils.

(3) Deep seasonal frost: composite sand-wedge casts.

(4) Seasonal frost: frost cracks, small or isolated cryoturbations.

The palaeoclimatic evolution of western and central Europe during the Weichselian Pleniglacial shows two main periods of continuous permafrost (c. 72-61 ka and c. 27-17 ka), a milder period in between with deep seasonal frost and periods with sporadic or discontinous permafrost (especially c. $35-41 \mathrm{ka}$ ). There is definite proof 
for permafrost during the Weichselian Early Glacial. The Late Glacial is characterized by a short period with discontinuous permafrost (c.10.9$10.5 \mathrm{ka})$. These conclusions apply to regions at about sea level; higher areas may show more rigorous conditions.

\section{REFERENCES}

Bohncke, S., Vandenberghe, J., Coope, G. and Reiling, R. (1987). Geomorphology and palaeoecology of the Mark valley (S. Netherland): palaeoecology, palaeohydrology and climate during the Weichselian Late Glacial. Boreas, 16, 69-85.

Brown, R. J. E. (1969). Factors Influencing Discontinuous Permafrost in Canada, In The Periglacial Environment, Past and Present. T. L. Péwé (ed.) McGill-Queen's University Press, Montreal, pp. 1153.

Brown, R. J. E. and Péwé, T. L. (1973). Distribution of permafrost in North America and its relationship to the environment: a review. In Permafrost, North American Contribution to Second International Conference on Permafrost, Yakutsk. National Academy of Sciences, Washington, D.C., Publication 2005, pp. 71-100.

Bryant, I. D. (1983). Facies sequences associated with some braided river deposits of late Pleistocene age from southern Britain. Special Publication International Association Sedimentology, 6, 267-275.

Cailleux, A., Guilcher, A. and Tricart, J. (1956). Phénomènes périglaciaires d'âge présumé Würm. Cartes des phénomènes périglaciaires quaternaires en France. Carte Géologique Détaillée de la France. Mémoires. pp. 34, Planche III.

Coope, G. R., Morgan, A. and Osborne, P. J. (1971). Fossil Coleoptera as indicators of climatic fluctuations during the last glaciation in Britain. Palaeogeogeography, Palaeoclimatology, Palaeoecology, 10, 87-101.

De Blaere, C. and Gullentops, F. (1986). Lithostratigraphie de la Grotte Scladina. Bulletin de l'Association Française pour l'Etude du Quaternaire, 1-2, $178-181$.

De Gans, W. (1981). The Drentsche Aa Valley System. PhD Thesis, Free University, Amsterdam. 132 pp.

De Groot, T., Cleveringa, P. and Klijnstra, B. (1987). Frost-mound scars and the evolution of a Late Dryas environment (northern Netherlands). Geologie en Mijnbouw, 66, 239-250.

De Moor, G. and Heyse, I. (1978). Dépôts quaternaires et géomorphologie dans le nord-ouest de la Flandre. C.R. de l'excursion du 23 octobre 1976. Bulletin van de Belgische Vereniging voor Geologie, 87 , 37-47.

De Moor, G., Heyse, I. and De Groote, V. (1978). An outcrop of Eemian and Early Weichselian deposits at
Beernem (N.W. Belgium). Bulletin van de Belgische Vereniging voor Geologie, 87, 27-36.

De Ploey, J. (1961). Morfologie en Kwartair-stratigrafie van de Antwerpse Kempen. Acta Geographica Lovaniensia, $1.130 \mathrm{pp}$.

Dewez, V., Lagarec, D. and Phipps, M. (1985). The Distribution of Some Landforms in Northern Quebec (Canada) as Related to Climate: An Information System Approach. Notes de Recherches, 47, Dépt. Géogr. Univ. Ottawa. 36 pp.

Eissmann, L. (1981). Periglaziäre Prozesse und Permafroststrukturen aus sechs Kaltzeiten des Quartärs. Altenberger Naturwissenschaftliche Forschungen, 1. $171 \mathrm{pp}$.

French, H. and Gozdzik, J. (1988). Pleistocene epigenetic and syngenetic frost fissures, Belchatow, Poland. Canadian Journal of Earth Sciences, 25, 2017-2027.

Gewelt, M. and Ek, C. (1988). Les concrétions carbonatées des grottes: aperçu synthétique. T. L. Péwé (ed.), Annales de la Société Géologique de Belgique, 111, 9-19.

Gozdzik, J. (1973). Origin and Stratigraphical Position of Periglacial Structures in Middle Poland. (In Polish with English summary.) Acta Geographica Lodziensia, $31.119 \mathrm{pp}$.

Gozdzik, J. (1986). Structures de fentes à remplissage primaire sableux du Vistulien en Pologne et leur importance paléogéographique. Biuletyn Peryglacjalny, 31, 71-105.

Gullentops, F., Mullenders, W. and Coremans, $M$. (1966). Etude de la plaine alluviale du Kaatsbeek à Diepenbeek. Acta Geographica Lovaniensia, 4, 141150.

Gullentops, F., Paulissen, E. and Vandenberghe, J. (1981). Fossil periglacial phenomena in NE-Belgium. Biuletyn Periglacjalny, 28, 345-365.

Haesaerts, P. (1974). Séquence paléoclimatique du Pleistocène supérieur du bassin de la Haine. Annales de la Société Géologique de Belgique, 97, 105-137.

Haesaerts, P. and Van Vliet-Lanoë, B. (1981). Phénomènes périglaciaires et sols fossiles observés à Maisières-Canal, à Harmignies et à Rocourt. Biuletyn Peryglacjalny, 28, 291-325.

Haest, R., Munaut, A., Huysmans, L., Gullentops, F. and Mook, W. (1986). La stratigraphie de BeerseDam (Belgique). Bulletin de l'Association Française pour l'Etude du Quaternaire, 1/2, 158-167.

Harry, D. G. and Gozdzik, J. (1988). Ice wedges: growth, thaw transformation, and paleoenvironmental significance. Journal of Quaternary Science, 3, 39-55.

Huijzer, A. (1991). Kesselt micromorphological analysis of the late Middle and Upper Pleniglacial (Weichselian) sequence of Kesselt (Belgium). In Excursion Guide, Symposium on Periglacial Environments in Relation to Climatic Change, 3-6 May 1991, Maastricht-Amsterdam, pp. 61-65. 
Johnson, Gr. (1984). Ice-wedge polygons and other periglacial phenomena in intermorainic sediments in the Oeresund area, southern Sweden. Geologiska Föreningens $i$ Stockholm Förhandlingar, 105, 341348.

Kaiser, K. (1960). Klimazeugen des periglazialen Dauerfrostbodens in Mittel- und West-Europa. Eiszeitalter und Gegenwart, 11, 121-141.

Karte, J. (1979). Räumliche Abgrenzung und regionale Differenzierung des Periglaziärs. Bochumer Geographische Arbeiten, 35, 1-211.

Karte, J. (1988). Das Pleistozäne Periglaziär im nordöstlichen Rheinischen Schiefergebirge. Berichte zur Deutschen Landeskunde, 62-2, 371-384.

Kasse, C. and Bohncke, S. (1992). Weichselian Upper Pleniglacial eolian and ice-core morphology in the southern Netherlands (Noord-Brabant, Groote Peel). Permafrost and Periglacial Processes, 3 (4), 327-342.

Kolstrup, E。 (1980). Climate and stratigraphy in northwestern Europe between 30,000 B.P. and 13,000 B.P with special reference to the Netherlands. Mededelingen van de Rijks Geologische Dienst, 31-15, 181253.

Kolstrup, E. (1987). Frost-wedge casts in western Jutland and their possible implications for European periglacial research. Zeitschrift für Geomorphologie N.F., 31, 449-461.

Kozarski, S. (1974) Evidence of late-Würm permafrost occurrences in northwest Poland. Quaestiones Geographicae, 1, 65-86.

Kozarski, S. (1986). Early Vistulian permafrost occurrence in North-West Poland. Biuletyn Peryglacjalny, 31, 163-170.

Kozarski, S. (1992). Upper Plenivistulian deglaciation and the periglacial zone expansion in NW Poland. Geologie en Mijnbouw (in press).

Lautridou, J.-P. and Sommé, J. (1981). L'extension des niveaux repères périglaciaires à grandes fentes de gel de la stratigraphie du Pleistocène Récent de la France du Nord-Ouest. Biuletyn Peryglacjalny, 28, 179-185.

Liedtke, H. (1957/58). Frostbodenstrukturen aus dem norddeutschen Jungmoränengebiet. Wissenschaftliches Zeitschrift der Humboldt-Universität Berlin, Math.-Nat. Reihe, 7, 359-376.

Lozinski, W. (1909). Ueber die mechanische Verwitterung der Sandsteine im gemässigten Klima. Academia Sci. Cracovic. Bull. Int., Cl. Sci. Math. et Naturelle, I, 1-25.

Maarleveld, G. (1976). Periglacial phenomena and the mean annual temperature during the last glacial time in The Netherlands. Biuletyn Peryglacjalny, 26, 5778.

Mullenders, W. and Gullentops, F. (1969). The age of the pingos of Belgium. In Péwé, T. (Ed.), The Periglacial Environment. McGill-Queen's University Press, Montréal, pp. 321-335.

Nelson, F. (1989). Permafrost zonation in eastern
Canada: review of published maps. Physical Geography, 10, 233-248.

Paepe, R. and Pissart, A. (1969). Periglacial structures in the Late-Pleistocene stratigraphy of Belgium. Biuletyn Periglacjalny, 20, 321-336.

Paepe, R. and Van Hoorne, R. (1967). The stratigraphy and paleobotany of the Late Pleistocene in Belgium. Mémoires Explicatives des Cartes Géologiques et Minières de la Belgique, 8, 1-96.

Pewé, T. L. (1966). Paleoclimatic significance of fossil ice wedges. Biuletyn Peryglacjalny, 15, 65-73.

Pissart, A. (1956). L'origine périglaciaire des viviers des Hautes Fagnes. Annales de la Société Géologique de Belgique, 74, 119-131.

Pissart, A. (1982). Déformations de cylindres de limon entourés de graviers sous l'action d'alternances gel/ dégel. Biuletyn Peryglacjalny, 29, 219-229.

Pissart, A. (1983). Remnants of periglacial mounds in the Hautes Fagnes (Belgium): structure and age of the ramparts. Geologie en Mijnbouw, 62, 551555.

Pissart, A. (1987). Géomorphologie Périglaciaire. Université de Liège, Laboratoire de Géomorphologie. $135 \mathrm{pp}$.

Pissart, A., Van Vliet-Lanoë, B., Ek, C. and Juvigné, E. (1988). Traces of ice in caves: evidence of former permafrost. In Proceedings Fifth International Conference on Permafrost. Vol 1. Tapir Publishers, Trondheim, pp. 840-845.

Poser, H. (1948). Boden- und Klimaverhältnisse in Mittel- und Westeuropa während der Würmeiszeit. Erdkunde, 2, 53-68.

Ran, E. (1990). Dynamics of vegetation and environment during the Middle Pleniglacial in the Dinkel valley (The Netherlands). Mededelingen van de Rijks Geologische Dienst, 44-3, 141-205.

Rohdenburg, H. (1967) Eiskeilhorizonte in südniedersächsichen und nordhessischen Lössprofilen. Biuletyn Peryglacjalny, 15, 225-245.

Romanovsky, N. H. (1985). Distribution of recent active ice and soil wedges in the U.S.S.R. In Church, M. and Slaymaker, O. (Eds), Field and Theory: Lectures in Geocryology. University of British Columbia, pp. 154-165.

Smith, M. W. (1975). Microclimatic influences on ground temperatures and permafrost distribution, Mackenzie Delta, N.W.T. Canadian Journal of Earth Sciences, 12, 1421-1438.

Sparks, B., Williams, R. B. G. and Bell, F. (1972). Presumed ground-ice depressions in East Anglia. Proceedings of the Royal Society of London, A327, 329-343.

Svensson, H. (1988). Ice-wedge casts and relict polygonal patterns in Scandinavia. Journal of Quaternary Science, 3, 57-67.

Vandenberghe, J. (1983a). Some periglacial phenomena and their stratigraphical position in the Weichselian deposits in The Netherlands. Polarforschung, 53, 97-107. 
Vandenberghe, J. (1983b). Ice-wedge casts and involutions as permafrost indicators and their stratigraphic position in the Weichselian. In Proceedings Fourth International Conference on Permafrost, Fairbanks, Alaska, Vol. 1. National Academy Press, Washington, D.C., pp. 1298-1302.

Vandenberghe, J. (1985). Paleoenvironment and stratigraphy during the Last Glacial in the BelgianDutch border region. Quaternary Research, 24, 23 38

Vandenberghe, J. (1988). Cryoturbations. In Clark, M. J. (Ed.), Advances in Periglacial Geomorphology. Wiley, Chichester, pp. 179-198.

Vandenberghe, J. (1992a). Geomorphology and climate of the cool oxygen isotope stage 3 in comparison with the cold stages 2 and 4 in the Netherlands. Zeitschrift für Geomorphologie, Supplement-Band, 86, 65-75.

Vandenberghe, J. (1992b). Cryoturbations: a sediment structural analysis. Permafrost and Periglacial Processes, 3, (4), 343-352.

Vandenberghe, J., Bohncke, S., Lammers, W. and Zilverberg, L. (1987). Geomorphology and palaeoecology of the Mark valley (southern Netherlands): geomorphological valley development during the Weichselian and Holocene. Boreas, 16, $55-67$

Vandenberghe, J., Bohncke, S. and Verbruggen, $M$. (1991). Interactions between the Late Glacial fluvial and aeolian processes and environments in Dutch lowland basins. Proc. Symp. IGCP-158A, Leuven (België) 1986, Aardkundige Mededelingen, 6, (in press).

Vandenberghe, J. and Gullentops, F. (1977). Contribution to the stratigraphy of the Weichselian pleniglacial in the Belgian coversand area. Geologie en Mijnbouw, 56, 123-128.

Vandenberghe, J. and Kasse, K. (1993). Periodic icewedge formation and Weichselian cold-climate floodplain sedimentation in the Netherlands. In Proceedings Sixth International Conference on Permafrost, Beijing (in press).

Vandenberghe, J. and Krook, L. (1981). Stratigraphy and genesis of Pleistocene deposits at Alphen (southern Netherlands). Geologie en Mijnbouw, 60, $417-426$

Vandenberghe, J. and Krook, L. (1985). La stratigraphie et la genèse de dépôts Pleistocènes à Goirle (Pays-Bas). Bulletin de l'Association Française pour l'Étude du Quaternaire, 1985-4, 239-247.

Vandenberghe, J., Mücher, H. J., Roebroeks, W. and Gemke, D. (1985). Lithostratigraphy and palaeoenvironment of the Pleistocene deposits at Maastricht-Belvédère, Southern Limburg, The Netherlands. Mededelingen van de Rijks Geologische Dienst, 39-1, 7-18.

Vandenberghe, J. and Van den Broek, P. (1982). Weichselian convolution phenomena and processes in fine sediments. Boreas, 11, 299-315.
Van der Hammen, T. (1957). A new interpretation of the Pleniglacial stratigraphical sequence in Middle and Western Europe. Geologie en Mijnbouw, 19, 493-498.

Van der Hammen, T. and Maarleveld, G. (1952). Genesis and dating of the periglacial deposits at the eastern fringe of the Veluwe. Geologie en Mijnbouw, 14, 47-54.

Van der Hammen, T., Maarleveld, G., Vogel, J. and Zagwijn, W. (1967). Stratigraphy, climatic succession and radiocarbon dating of the last glacial in The Netherlands. Geologie en Mijnbouw, 46, 79-95.

Van der Hammen, T. and Wijmstra, T. (1971). The Upper Quaternary of the Dinkel valley. Mededelingen van de Rijks Geologische Dienst N.S., 22, 55-213.

Van der Meer, J., Slotboom, R. and De VriesBruynsteen, I. (1984). Lithology and palynology of Weichselian alluvial fan deposits near Eerbeek, The Netherlands. Boreas, 13, 393-402.

Van der Tak-Schneider, U. (1968). Cracks and fissures of post-Alleröd age in The Netherlands. Biuletyn Peryglacjalny, 17, 221-225.

Van Geel, B., Coope, G. R. and Van der Hammen, T. (1989). Paleoecology and stratigraphy of the Lateglacial type section at Usselo (The Netherlands). Review of Paleobotany and Palynology, 60, 25129.

Van Huissteden, J. (1990). Tundra Rivers of the Last Glacial: sedimentation and geomorphological processes during the Middle Pleniglacial in Twente, Eastern Netherlands. Mededelingen van de Rijks Geologische Dienst, 44-3, 3-138.

Van Vliet-Lanoë, B. (1983). Etudes Cryopédologiques au Sud $d u$ Kongsfjord-Svalbard. Publications du Centre de Gémorphologie, Caen. 39 pp.

Van Vliet-Lanoë, B. (1989). Dynamics and extent of the Weichselian permafrost in Western Europe (substage $5 \mathrm{E}$ to stage 1 ). Quaternary International, 3/4, 109-113.

Velichko, A. A. (1982) Paleogeography of Europe During the Last One Hundred. Thousand Years (atlas monograph in Russian with abstract and legends in English). (I. P. Gerassimov, Ed.). Nauka, Moscow. 156 pp., 14 planches.

Washburn, A. L. (1979). Geocryology. Edward Arnold, London.

Washburn, A. L. (1980). Permafrost features as evidence of climatic change. Earth Science Reviews, 15, 327-402.

West, R., Dickson, C., Catt, J., Weir, A. and Sparks, B. (1974). Late Pleistocene deposits at Wretton, Norfolk. II. Devensian deposits. Philosophical Transactions of the Royal Society of London, B267, $337-420$.

Williams, R. B. G. (1975). The British climate during the Last Glaciation; an interpretation based on periglacial phenomena. In Wright, A. E. and Moseley, F. (Eds), Ice Ages; Ancient and Modern. Geological 
Society Special Issue No. 6, Seel House Press, Liverpool, pp. 95-120.

Woillard, G. and Mook, W. (1982). Carbon-14 dates at Grande Pile: correlation of land and sea chronologies. Science, 215, 159-161.

Zagwijn, W. (1974). Vegetation, climate and radiocarbon datings in the Late Pleistocene of the Nether- lands, Part II: Middle Weichselian. Mededelingen van de Rijks Geologische Dienst N.S., 25, 101110.

Zagwijn, W. and Paepe, R. (1968). Die Stratigraphie der weichselzeitlichen Ablagerungen der Niederlande und Belgiens. Eiszeitalter und Gegenwart, 19, 129146. 